\title{
EFFECTIVENESS OF TRANSPOSED EU EQUALITY LAW IN THE CZECH REPUBLIC
}

\begin{abstract}
Barbara Havelková*
Summary: Although the acquis communautaire relating to gender equality has largely been transposed in the Czech Republic, this does not necessarily mean that these rules are being fully implemented. Almost two years after accession to the EU, the equally important implementation phases - namely, application (establishment of procedures and administration of measures by the relevant authorities) and enforcement (monitoring by the relevant authorities and ensuring or compelling conformity) - are severely underdeveloped, and compliance by the private sector is at a low level. Little attention is paid to continuous policy evaluation, i.e. checking whether the adopted methods of application and enforcement are bringing about the desired results, or subsequent policy reform, i.e. learning from lessons drawn from the evaluation stage. ${ }^{1}$

In this paper, the individual stages of implementation will be looked at in order to determine possible challenges to the effectiveness of equality law at the national level. Effectiveness here is understood, following Snyder," as the fact that "law matters: it has effects on political, economic and social life outside the law - that is, apart from simply the elaboration of legal doctrine".
\end{abstract}

\footnotetext{
" Mgr. (M.A. in law, Charles University in Prague), JUDr. (rigorous theses in law, Charles University in Prague). Currently enrolled in the Master's Programme "European Integration" at the Europa-Institut of Saarland University, Germany; simultaneously pursuing a PhD at the Law Faculty of Charles University in Prague, Czech Republic. All translations are the author's, unless otherwise indicated. This article reflects the legal situation in the Czech Republicas of 1st June 2006.

${ }^{1}$ The distinction between transposition, application, enforcement, compliance, policy evaluation and policy reform as phases of policy implementation is taken from P Nicolaides, Enlargement of the EU and Effective Implementation of its Rules (EIPA, Maastricht 2000). These phases correspond to Snyder's differentiation between the seven types of effectiveness of Community law. Those relevant to this paper concern the national level: the transposition of Community directives into national law; the implementation of Community secondary legislation, or national transposing or implementing legislation, within or by the national civil service; the use of Community law by economic undertakings; recourse to litigation in a national court based on Community law; and the enforcement of Community law by national courts (items 3 to 7 in Snyder's numbering). F Snyder, 'The Effectiveness of European Community Law. Institutions, Processes, Tools and Techniques' (1993) 56 MLR 25.

${ }^{2}$ F Snyder, New Directions in European Community Law (Weidenfeld \& Nicholson, London 1990), 3.
} 


\section{Transposition}

Community law provisions have largely been transposed into Czech labour law. The anti-discrimination formulas introduced into the Labour Code $^{3}$ in 2000 by the first "Euro-amendment" ${ }^{4}$ were enhanced and elaborated in $2004^{5}$ (e.g. definitions of direct and indirect discrimination, harassment and sexual harassment were added, and positive action was allowed). ${ }^{6}$ Anti-discrimination provisions were also added to the Employment Act, ${ }^{7}$ which regulates access to employment, the State Service Act, ${ }^{8}$ and the Military Service Act. ${ }^{9}$

Apart from enhancing the existing law with anti-discrimination provisions, some traditional provisions not reconcilable with the principle of gender equality were removed. For example, Ministry of Health Ordinance $261 / 1997$, which forbade certain kinds of work and working conditions to women, has been abolished.

Some problems in the area of approximation of laws remain, however. First, some transposition is only apparent, as the laws containing anti-discrimination provisions have not yet come into effect. This is the case with the State Service Act and the Military Service Act, which were to enter into force as of 1 January 2005, but whose effectiveness has been postponed due to financial problems (the current anticipated date is 1 January 2007). This is especially problematic in that anti-discrimination provisions were not added to the acts currently in force. Consequently, employment relations in the police or prison services, for example, are not governed by any anti-discrimination provisions.

Second, some rigorous protectionist provisions have not been abolished. Part II, Chapter VII of the Labour Code thus still forbids the employment of women in work performed underground.

\footnotetext{
${ }^{3}$ Act No. 65/1965 Coll.

${ }^{4}$ Act No. 155/2000 Coll.

${ }^{5}$ Act. No. 46/2004 Coll.

${ }^{6}$ The amendment transposed the European Community's new anti-discrimination directives, namely:

1) Council Directive (EC) 2000/43 of 29 June 2000 implementing the principle of equal treatment between persons irrespective of racial or ethnic origin [2000] OJ L185/5

2) Council Directive 2000/78 (EC) of 27 November 2000 establishing a general framework for equal treatment in employment and occupation [2000] OJ C177/42 E.

3) Council Directive 2002/73 (EC) amending Council Directive 76/207 (EEC) on the implementation of the principle of equal treatment for men and women as regards access to employment, vocational training and promotion, and working conditions [2002] OJ L269/15-20.

7 Act No. 435/2004 Coll.

${ }^{8}$ Act No. 218/2002 Coll., regulating employment in the public service.

${ }^{9}$ Act No. 361/2003 Coll., regulating employment relationships among police officers, firefighters, customs officers, prison guards, and members of the intelligence services.
} 
Third, the regulations are fragmented and heterogeneous. For example, the definition of sexual harassment differs in various acts. In the Labour Code, ${ }^{10}$ the Military Service Act ${ }^{11}$ and the Employment Act ${ }^{12}$ the definition of sexual harassment has been aligned with that of Directive 2002/73/EC. ${ }^{13}$ Their formulations vary, however, and none corresponds exactly with the one contained in the Czech version of the Directive. The State Service Act ${ }^{14}$ contains a more general ban on behaviour violating a person's dignity, ${ }^{15}$ one corresponding to the state of EC legal regulations prior to the amending Directive of 2002. Likewise, other institutes are regulated slightly differently across the body of law governing labour relations. This "diffusive approach" makes the scope of rights and obligations dependent on legal sources; moreover, in some areas, such as access to self-employed activity, the law offers no protection from discrimination at all. It has been argued that "the diffusive approach was inappropriate for addressing a very wide range of European directives pertaining to selfemployment and dependent activities, regardless of whether they are performed in a labour-law relationship or not. Special laws do not completely cover the areas of relationships where the Communities demanded that the principle of equal treatment be implemented." ${ }^{16}$

To remedy these deficiencies, the government proposed a complex anti-discrimination law in 2003. ${ }^{17}$ The bill was passed by the Chamber of Deputies on 7 December 2005, but struck down by the Senate on 26 January 2006. It has been returned to the Chamber of Deputies, which can outvote the Senate by an absolute majority.

Fourth, a gender perspective has not been taken into account in all areas when preparing new legislation. Thus the new "common taxation of spouses" amendment to the Income Tax Act, effective as of 1 January

\footnotetext{
${ }^{10}$ Act No. 65/1965 Coll. ss 8(1) and 9

11 Act No. 361/2003 Coll. s 5(77)

${ }^{12}$ Act No. 435/2004 Coll. ss 7(4) and 8

13 n 6.

14 Act No. 218/2002 Coll. s 3(80)

15 This provision, which also forbids unwanted sexual behaviour, implements Council Directive (EEC) 76/207 on the implementation of the principle of equal treatment for men and women as regards access to employment, vocational training and promotion, and working conditions [1976] OJ L39/40-42. According to the explanatory report, the formulation stems from the Council Resolution (EEC) 90/C 157/02 of 29 May 1990 on the protection of the dignity of women and men at work [1990] OJ C157, and the Commission Recommendation (EEC) 92/131 of 27 November 1991 on the protection of the dignity of women and men at work [1992] OJ L049/1-8.

${ }^{16}$ P Boučková, 'The legal framework for promotion of equal treatment and equal opportunities' in P Pavlik (ed), Shadow Report on the Fulfilment of the Priorities and Procedures of the Czech Government (Gender Studies, o.p.s., Prague 2004), 37.

17 Enacting a complex anti-discrimination law is the approach taken by most neighbouring states, e.g. Germany, Austria and Slovakia.
} 
$2006,{ }^{18}$ is insensitive to developments concerning non-traditional forms of family life. It allows spouses supporting at least one child who lives with them in one household to calculate taxes from a common tax base. This most benefits "traditional" families where the father has a high income, while the mother has none at all and looks after the house and children (this combination of one high and one non-existent income puts the couple in a lower tax range). The law disadvantages double income families especially where both spouses are high-earning, single parents or unmarried couples.

The overall problem with regard to legal regulations is, however, the absence of genuine interest in achieving the goal of the legislation namely, gender equality - and the lack of high-level political will to push through certain changes.

According to legal sociology, ${ }^{19}$ the first requirement for effective legislation is to formulate its desired effect on society, establish a clear goal, and subsequently focus the legislation on achieving this goal (choosing the means, distribution of rights and obligations, and so on). The European Community has committed itself to the aim of achieving equality in wages, treatment and social security as essential parts of its social policy (as indicated by Art. 141 of the EC Treaty signed in Amsterdam, the adoption of a series of directives, and decisions by the Court of Justice of the European Communities ${ }^{20}$ ). At the national level, however, the goal of these regulations is somewhat distorted. The legislator's actual aim was to harmonise Czech law with Community law; the Czech legislator was primarily concerned not with equality, but with accession. This can be illustrated by the appeal made by Vice Prime Minister and Minister of Justice Pavel N mec during parliamentary discussion of the anti-discrimination bill, ${ }^{21}$ where he pleaded with the deputies and senators to pass the bill solely by reason of the Czech Republic's international obligations towards the EU: "I would like to remind you what this law is about. This law actually deals with implementing the Czech Republic's international obligations, which are binding on the Czech Republic, and introducing them into its legal order." 22

\footnotetext{
${ }_{18}$ Act No. 586/1992 Coll. para 13a

19 Roger Cotterrell's summary of theories on 'Law as an Instrument of Legal Change' in R Cotterrell,, The Sociology of Law: An Introduction (Butterworths, London 1992), 44-65.

${ }^{20}$ Case 149/77 Defrenne v Sabena. [1978] ECR 1365, paras 26-27 (Defrenne III).

${ }^{21}$ Introduction of the government bill on 10 February 2005 in the Chamber of Deputies, on 26 January 2006 in the Senate, and again in the lower house on 15 March 2006 <www.psp. cz> and <www.senat.cz> accessed 16 March 2006.

${ }^{22}$ Chamber of Deputies session, discussions on 15 March 2006

<http://www.psp.cz/eknih/2002ps/stenprot/054schuz/s054224.htm\#rl>accessed 16 March 2006.
} 
Furthermore, the anti-discrimination bill passed through the legislative process without much ado; no explanations of the juridical institutes were presented, and no discussion was initiated by the government. While avoiding discussion of controversial issues such as positive action or sexual harassment might be the government's strategy, it has not been a very successful one. The bill has been misunderstood by political opponents ("The law introduces concepts which are unclear und difficult to interpret. For example, harassment [...] What is an intimidating environment?"23) and attacked by conservative groups ("[S]exual deviation will soon be grounds for a discrimination claim before the courts" 24 ; "[T]he law will not help anybody, but will provide sufficient means of annoying employers and service providers through litigation"25), and remains to a great extent undefended by the government.

The problem is, as we have mentioned, the lack of a credible information campaign which would show the need for an anti-discrimination law and explain the concepts it introduces, as well as the non-existence of top-level political negotiations aimed at gaining support for the bill (deputies from the government parties supported the bill, while the Communist Party, which might have been persuaded for ideological reasons, was opposed ${ }^{26}$ ).

\section{Application and enforcement}

Application and enforcement of the new equality rules lies with the courts and administrative bodies.

\section{Courts}

Before analysing two recent judgments in discrimination cases, some general challenges facing courts' proper application of the antidiscrimination law should be mentioned. As these norms were adopted with regard to the Czech Republic's accession to the EU, and are thus transpositions of Community law, two problems arise: first, systemic and interpretative difficulties and, second, insufficient understanding of antidiscrimination provisions.

First, the problem of using and interpreting hitherto unknown sources of law (the systemic and interpretative problem) affects the appli-

\footnotetext{
${ }^{23}$ Statement by Senator Škaloud in discussions in the Senate on 26 January 2006 <www. senat.cz> accessed 16 March 2006.

${ }^{24}$ Website of the "Traditional Family" group <www.tradicnirodina.cz> accessed 5 March 2006.

25 , Website of the "Pro-life" group <zakony.prolife.cz> accessed 5 March 2006.

${ }^{26}$ Voting records at <www.psp.cz> accessed 16 March 2006.
} 
cation of anti-discrimination rules. For example, when a Czech judge is faced with a wage discrimination case, he or she will have to apply the provisions of the Labour Code ${ }^{27}$ and the Wage Act, ${ }^{28}$ as well as rules governing the burden of proof contained in the Civil Procedure Code, ${ }^{29}$ but will also have to apply Art. 141 EC Treaty, which has a horizontal direct effect, and the interpretation of that article by the Court of Justice of the European Communities (the ECJ). In case of doubt as to the meaning of norms originating in EC Directives, ${ }^{30}$ he or she would also have to bear in mind the purpose of the Community provisions as elaborated in the preambles to these Directives; these are not legally binding and, therefore, have not been transposed. This means that certain parts of the legal norm, and also often its rationale (which is a prerequisite for teleological interpretation), are not to be found in the usual sources of Czech law.

Second, the effectiveness of any legal norm requires a high degree of clarity and comprehensibility. The wording of these norms mainly translates Community law provisions which stem from the legal traditions of the older Member States. Some of their terms were familiar before Czech law was harmonised with EC law, yet have not been defined and developed by the courts or legal doctrine (e.g. "equality" or "disparate treatment"), while others were introduced only by the acquis communautaire (e.g. "indirect discrimination" or "sexual harassment"). Neither the terms known before accession nor the newer ones are related to any well-established notion in the Czech Republic, be it among the general public or within the legal community. However, these norms do have a content; they are often complex institutes in which subsuming facts under the norm requires testing by means of a series of questions. ${ }^{31}$ Many Czech lawyers, however, consider these provisions self-explanatory and their interpretation unproblematic, leading to errors of argumentation in petitions made by legal counsel and decisions made by courts.

Given the novelty of the anti-discrimination provisions, not enough time has elapsed to allow disputes to be litigated before the higher courts. This causes a problem where the accessibility of judgments is concerned (rulings by district and regional courts are never published, and only

\footnotetext{
${ }^{27}$ Act No. 65/1965 Coll. para 1

${ }^{28}$ Act No. 1/1992 Coll. para 4a

${ }^{29}$ Act No. 99/1963 Coll. para 133a

${ }^{30}$ In particular, Council Directive (EEC) 75/117 of 10 February 1975 on approximation of the laws of the Member States relating to the application of the principle of equal pay for men and women [1975] OJ C55/43; and Council Directive (EC) 97/80 of 15 December 1997 on the burden of proof in cases of discrimination based on sex [1997] OJ L014/6-8.

${ }^{31}$ For example, the institute of indirect discrimination has been interpreted in detail by the ECJ, which has also developed a three-step test: 1) Has there been disparate treatment with different groups of employees? 2) Is one sex substantially more represented in the disadvantaged group? and 3) Can an objective reason justify the disparity in treatment?
} 
some of those made by higher courts are). More importantly, it is not yet possible to infer any interpretative tendencies from the incidental and fragmented decisions which are available. Even if not representative or final, examples of the application of anti-discrimination provisions by courts are useful at this stage in illustrating the misunderstanding and misapplication of equality norms (in both substantive and procedural law).

Thus, in a case of age discrimination in access to employment (36 C 64/2003), the judge stated that "the Court did not establish the reason for rejection of the job application, as this is irrelevant to an appraisal of the case". It must be emphasised that the reason for differential treatment (i.e. age) is a crucial element in establishing discrimination. Moreover, the court chose to ignore certain pertinent legal rules, stating that Act No. 1/1991 on Employment contains only public law obligations, and cannot be invoked by a job applicant against a potential employer (which is inconsistent with the legal doctrine concerning the Act). This decision was not appealed, as the plaintiff committed suicide shortly after the judgment was pronounced.

One example of disregard for procedural law can be found in the decision (23 C 11/2003) in a case of direct discrimination in remuneration, where the judge did not apply the provision of Art. 133a of Act No. 99/1963 of the Civil Procedure Code, which regulates the shifting of the burden of proof from the plaintiff to the defendant.

\section{Administrative Bodies}

Enforcement of equality in the private sector lies with the Labour Offices and Labour Inspectorates. A July 2004 press release from the Ministry of Labour and Social Affairs ${ }^{32}$ indicates that 77 cases of wage discrimination had been discovered by the Labour Offices; however, this covers discrimination on all grounds and in the entire Czech Republic, and does not say anything about what sanctions were imposed. The government Report on the Fulfilment of the Priorities and Procedures of the Czech Government in Promoting the Equality of Men and Women ${ }^{33}$ states that proving discrimination is difficult, as written evidence is often lacking, and the real reasons for discrimination are often disguised by neutral explanations. This indicates that techniques for uncovering discrimination are unknown to these bodies.

\footnotetext{
${ }^{32}$ MLSA Press release, 'Úřady práce zkontrolovaly za pět měsíců 3887 firem' ('Labour Offices inspect 3887 companies in five months') 2 July $2004<$ http://www.mpsv.cz/files/ clanky/tiskovky/020704a.pdf> accessed 6 July 2004.

33 'Souhrnná zpráva o plnění „Priorit a postupůvlády při prosazování rovnosti mužůa žen“ v roce 2003' ('Report on the Fulfilment of the "Priorities and Procedures of the Czech Government in Promoting the Equality of Men and Women" ') 53, 12 May $2004<$ http://www.mpsv. cz/scripts/clanek.asp?lg=1\&id=696> accessed 6 July 2004.
} 
Misapplication of regulations (by judges, as shown above) and a low emphasis on enforcement (by officers and inspectors) could be connected to the aforementioned low comprehensibility (lack of understanding of equality provisions) and systemic problems (norms and tools for interpretation are not contained in the usual sources). Reports by various NGOs $^{34}$ also point to the fact that a basic understanding of gender issues is necessary in order to apply and enforce gender equality provisions, and that staff in public administration lack such expertise. Training of the personnel administering equality legislation is one way in which the government could enhance its implementation.

As far as specialised bodies dedicated to promoting gender equality, several of these have been established since 1998 to deal with issues of equality and discrimination against women: among others, the Unit for Equality between Men and Women of the Ministry of Labour and Social Affairs and the Government Council for Equal Opportunities for Men and Women (an advisory body to the Cabinet). Their authority is restricted to writing reports and issuing recommendations; none has the power to assign tasks, give binding instructions, or effectively supervise other government bodies, nor the competence to independently assist victims of discrimination within the meaning of Article 8a of Council Directive 2002/73/EC. ${ }^{35}$

When the government was preparing its universal anti-discrimination law, two solutions were put on the table. The first was adding this agenda to the competence of the Ombudsperson; the second (preferred by NGOs and the Ombudsman himself) proposed establishing a new entity, the Centre for Equal Treatment. When voting on which version of the bill to submit to Parliament, the government chose the former (cheaper and less systemic) option. Adding this to the Ombudsman's agenda goes against the logic of his office, which handles complaints of maladministration by the public authorities. The proposed agenda is much broader, and aims at the private sector as well. This systemic deficiency has been criticised by many, and was one of the arguments used by the Senate's Constitutional Committee in urging senators to reject the anti-discrimination bill. Equality policy has thus been marginalised by being inappropriately added to the agenda of an institution whose focus is substantially different, and this flawed institutional decision has, in turn, served as an argument for striking down the anti-discrimination bill as such.

${ }_{34} \mathrm{P}$ Pavlik (ed), Stínová zpráva v oblasti rovného zacházení a rovných příležitostí žen a mužů ('Shadow Report on Fulfilment of the Priorities and Procedures of the Czech Government') (Gender Studies, o.p.s., Prague, 2004), or B Havelková, 'National monitoring report on equal opportunities for women and men in the Czech Republic' in The EU and Equal Opportunities for Women and Men (Open Society Institute, Budapest 2005) <www.soros.org/women> accessed December 2005.

35 B Havelková, ibid. 
The Ombudsman himself is not particularly enthusiastic about the new agenda: "I had, and will continue to have, reservations, and I pointed these out to the government before any definite discussion of the [antidiscrimination] law: that this is non-systemic, that I will have to form two offices within one institution. One will remain a classic ombudsman's office [...], and then another section which would only remotely resemble an [ombudsman's] agenda." ${ }^{36}$ Representatives of NGOs $^{37}$ have pointed out that it was the Ombudsman who, during discussions of the antidiscrimination bill in the Chamber of Deputies, lobbied for removal of its provisions on mediation (which were indeed taken out), since handling mediation would mean an additional burden on his office's work. Among the Ombudsman's other powers are issuing recommendations and statements, independent analysis and monitoring, and providing information to the public. Given the Ombudsman's negative attitude, it is doubtful whether these tasks, which require a great understanding of the pertinent issues and true dedication, will be carried out.

In short, the prerequisite for effective implementation, namely, the establishment of functioning institutional mechanisms with sufficient resources (financial and human), has not been met thus far.

\section{Compliance}

The prerequisites for effective regulation ${ }^{38}$ include an awareness of the situation, an assessment of society's demand for regulation, and an evaluation of its compatibility with cultural and moral principles. These aspects were explored by EC institutions prior to adopting legislation ${ }^{39}$ in the Western societies of the older Member States, but not in the Czech Republic. Since an often-heard argument states that "there is no need for equality legislation in the Czech Republic", I would first like to discuss whether this is true - can Czech society be so "special"? Here I will consider some general tendencies, without looking at different actors in the private sphere individually.

As stated above, the main argument for adopting equality legislation was not the existence of gross inequalities in Czech society (which

\footnotetext{
${ }^{36}$ Václav Moravec, Interview with Dr. Otakar Motejl, the Ombudsman, (Prague, 8th December 2004) <www.bbc.cz> accessed 20 March 2006

37 Written interview with Pavla Boučková, Poradna pro občanství, občanská a lidská práva (Counselling Centre for Citizenship, Civil and Human Rights) (20 March 2006).

${ }^{38}$ R Cotterrell (n 19), 44-65. P Hungr et al., Sociologie práva (Sociology of Law) (MÚ, Brno 1992).

39 See, for example, the Preamble to Council Directive (EEC) 76/207 on the implementation of the principle of equal treatment for men and women as regards access to employment, vocational training and promotion, and working conditions [1976] OJ L39/40-42, , which refers to the third clause of the Preamble to the Council Resolution of 21 January 1974 concerning a social action programme [1974] OJ C13/1-4.
} 
would not be difficult to demonstrate), but obligations towards the EU. Considering the Czech communist past and the directed "equalisation" imposed by that regime, this top-down explanation is particularly harmful to the policy's effectiveness. It has been argued" ${ }^{40}$ that a "modernisation without liberation" took place under communism, where the two basic policies towards women were self-contradictory. On the one hand, women were deprived of their own voice and the possibility of acting independently (through laws prohibiting assembly, the elimination of all civic organisations, and total censorship of public speech); on the other, state policy clearly aimed at further modernisation of women's public status (policies ranged from the ideological advocacy of gender equality, women's access to education and to all professions, affirmative action in the sphere of political representation at both the state and local level, and a well-organised infrastructure of nurseries, kindergartens and after-school care for schoolchildren). Some of the guaranteed rights were taken for granted by Czech women (even though these had to be fought for in the West during the second wave of the feminist movement), while others were never internalised, being regarded as imposed "state feminism". Equality policy is thus viewed with a certain amount of suspicion today, partly because of its top-down character (anti-feminist and anticommunist resentments are often combined). It may be said, therefore, that the local gender culture to some extent inhibits the positive effects of equality legislation. However, to give a more balanced overall picture, it should be said that discussion of these issues in the Czech Republic has been developing, thanks to input from global feminist thinking as well as local activism, and that a gradual transformation of local gender culture may be observed.

A second observation relevant to the analysis of compliance with equality legislation is that equality regulations mostly concern labour relations, an area notorious for breaches of the law (although quantitative data are not available). The Labour Code of 1965, which has remained unchanged since communist times in many respects, is a very complex and rigid law that does not correspond to the current labour market. Thus the law is often completely circumvented: companies contract workers as self-employed persons with a trade licence, under a commercial law regime, rather than employing them under the regime of labour law. This so-called "Švarc system" 41 has been illegal since 1992, but remains

\footnotetext{
${ }^{40}$ European Commission, Report: 'Waste of talents: Turning private struggles into a public issue. Women and Science in the Enwise countries' 2003 <http://europa.eu.int/comm/ research/science-society/pdf/enwise_report2_fulltext-120704.pdf> accessed 15 January 2006.

${ }^{41}$ Named after a businessman who only contracted workers with trade licences for his outlet in Sazava, and who was prosecuted by the authorities in the early 1990s.
} 
common in practice. ${ }^{42}$ Even when a proper employment contract is concluded, many provisions of the Labour Code, ${ }^{43}$ in particular the rules on working time, ${ }^{44}$ are still breached. The equal treatment requirement is thus often dismissed as an additional burden on employers, who are already encumbered by other provisions of the Labour Code; and since broad non-compliance with the law is a given fact, violating the new rules is just business as usual.

A third remark concerns the low level of general knowledge of, and compliance with, the law in the Czech Republic. ${ }^{45}$ It should be pointed out that it has been very difficult - even for lawyers - to keep up with the precipitous development of the Czech legal system over the past 15 years (more than 500 regulations have been published annually in the Collection of Laws in recent years, and new legal acts are often amended before they even come into effect). Some difficulty in ascertaining what the law actually is should, therefore, be acknowledged.

However, I believe that this low level of general knowledge is also connected with a low level of motivation to get acquainted with the law. This could be because non-compliance is not viewed as something negative. The authorities themselves have not sent a clear message that the law should be obeyed. The Czech population witnessed a great disregard for the law under communism. It is not widely known that the famous dissident group "Charta 77" was only demanding that the government comply with its own laws - namely, the two UN international Covenants on human rights and on economic, social and cultural rights) to which it was a signatory. This trend continued well into the period of transition in the 1990s. Anecdotal evidence documenting this trend includes statements regarding privatisation made by the current Czech president, and then-prime minister, Václav Klaus: "Let's turn the light off for five minutes, privatise, and then turn it on again"; or, "There is no difference between clean money and dirty money".

As stated above, due to the atmosphere of tolerance towards noncompliance, motivation to know and comply with the law is weak. The lack of external motivation already described (unsatisfactory application

\footnotetext{
${ }^{42} \mathrm{~S}$ Cardais, 'State bans contract work abuse. Law aimed at cracking down on welfare payment evasion' Prague Post (Prague 19 May 2005) <http://www.praguepost.com/P03/2005/ Art/0519/busi2.php> accessed 5 April 2006.

${ }^{43}$ No exact quantitative data are available, but many analyses by the Výzkumný ústav práce a sociálních věcí (Research Institute for Labour and Social Affairs) indicate factual non-compliance. <http://www.vupsv.cz> accessed 5 April 2006.

${ }^{44}$ I Pleskot, 'Uplatňování politiky zaměstnanosti v souladu s potřebami trhu práce' ('Employment policy in conformity with the exigencies of the labour market') Výzkumný ústav práce a sociálních věcí (Prague, 2004) 9 <http://www.vupsv.cz/fulltext/uloha2.pdf>,accessed 5 April 2006.

${ }^{45}$ This claim cannot be supported by any statistical evidence.
} 
and enforcement by the authorities) is thus worsened by weak support for certain kinds of behaviour by other normative systems (morality). We might add that, although voluntary compliance with equality legislation seems to lie beyond the state's reach, it could be boosted by well-led information campaigns on gender equality legislation.

\section{Policy evaluation and policy reform}

The national plan of action, or national gender equality strategy, is called "Priorities and Procedures of the Czech Government in Promoting the Equality of Men and Women" (Priorities), and contains, among other things, a chapter on "legal support for gender equality and raising legal awareness". The plan is updated annually, and its implementation is monitored. The monitoring and evaluation process is, however, flawed to a great extent, as fulfilment of the Priorities is assessed by the departments of the individual ministries responsible for carrying them out. The veracity of these self-evaluations is questionable, for obvious reasons. NGO reports point to the fact that progress in this area is often too easily deemed adequate, few lessons are learned, and little genuine policy reform resulting from critical policy evaluation may be seen. ${ }^{46}$

\section{Conclusions}

As we have seen, there are many challenges to the effectiveness of equality legislation in the Czech Republic. Some of these are of a general nature (low compliance with the law, and with labour law in particular), while others are connected with the origin of equality norms in EC law (application and interpretation of new legal concepts), or are gender-related (rejection of anti-discrimination provisions by private actors).

It has also been shown that there is room for improvement regarding the effectiveness of equality legislation. Overall awareness and understanding will probably improve with time, but the burden is also on the legislator and the government to pay greater attention to the "technique element" in law ${ }^{47}$ (assigning the agenda to more appropriate institutions, allocation of resources, information campaigns, and so forth). The difficulty of influencing society by means of the law must be recognised. Yet in order to have at least a chance of succeeding, all six elements of implementation - transposition, application, enforcement, compliance, policy evaluation and policy reform - must be given particular attention in order for the regulations to be effective.

${ }^{46}$ B Havelková (n 34).

${ }^{47}$ R Cotterrell (n 19), 64. 